\title{
Peranan Wanita Karier Dalam Keluarga, Pola Asuh Dan Pendidikan Anak (Studi Kasus Pada Wanita Karier Pada Jl. Anggrek Rt 002/018 Pondok Benda Pamulang Tangerang Selatan).
}

\author{
Ana Septia Rahman, S.Pd.I, M.M. \\ Dosen Fakultas Ekonomi Universitas Pamulang \\ Email :dosen01709@unpam.ac.id
}

\begin{abstract}
ABSTRAK
Penelitian ini bertujuan untuk mengetahui peran wanita karier dalam keluarga, pola asuh dan pendidikan anak. Masalah dalam penelitian ini adalah bagaimana peran wanita karier dalam keluarga, pola asuh dan pendidikan anak, dan faktor apa saja yang mendukung dan menghambat peran wanita karier dalam keluarga, pola asuh (mengasuh) dan pendidikan anak. Metode yang digunakan dalam penelitian ini adalah penelitian kualitatif dengan metode deskriptif. Sumber data dalam penelitian ini ada dua jenis yaitu data primer dan data sekunder. Adapun teknik pengumpulan data yang digunakan adalah teknik observasi, wawancara, kuesioner, studi kepustakaan dan dokumentasi.

Berdasarkan sumber data penelitian, informan di dalam penelitian ini ada 4 orang wanita karier dengan berbagai profesi yaitu PNS (2 orang), Pegawai Bank, dan Guru. Dan teknik analisis data yang digunakan adalah analisa kualitatif model interaktif. Hasil penelitian menunjukkan bahwa peran ganda bagi wanita karier tidaklah mudah, tetapi informan dan hasil dari responden menunjukkan bahwa wanita karier dapat melewati perannya tersebut dengan baik. Dengan menerapkan pola asuh demokratis, informan memberikan kebebasan pada anak untuk mengembangkan wawasannya tapi tetap ada pengawasan dari orang tua, dan memberikan bekal pendidikan moral dan agama pada anak mereka. Dan meskipun waktu menjadi faktor penghambat mereka dalam menjalankan peran sebagai ibu, istri dan pekerja, mereka tetap melaksanakan tanggung jawab mereka. Dan suami mereka mengizinkan mereka untuk bekerja.
\end{abstract}

Kata Kunci: Wanita Karier, Peran dalam Keluarga, Pola Asuh, dan Pendidikan anak 


\section{PENDAHULUAN}

Wanita memiliki peran yang amat besar dalam kehidupan bermasyarakat dan bernegara. Tanpanya, kehidupan tidak akan berjalan semestinya. Sebab ia adalah pencetak generasi baru. Pandangan yang berkembang dalam masyarakat mengenai status dan peran perempuan masih terbagi dalam dua kutub yang berseberangan. Di satu sisi, umumnya berpendapat bahwa perempuan harus di dalam rumah, mengabdi kepada suami, dan hanya mempunyai peran domestik. Di sisi lain, berkembang pula anggapan bahwa perempuan harus bebas sesuai dengan haknya tentang kebebasan.Dengan demikian, seiring dengan berkembangnya ilmu pengetahuan dan teknologi (IPTEK), yang mana perkembangan ilmu pengetahuan dan teknologi tersebut menuntut kemajuan pola pikir, serta pengetahuan yang luas bagi setiap individu. Jaminan sukses secara finansial, diakui untuk menyandang predikat mandiri mengharuskan wanita menjemput impian dengan belajar ke jenjang pendidikan yang lebih tinggi, mendapatkan pekerjaan yang bisa dihargai dan mendapat posisi yang tinggi dalam dunia pekerjaan. Kesempatan untuk memperoleh pendidikan dan kesempatan untuk mendapatkan pekerjaan sudah semakin terbuka luas.

Akan tetapi, pada kenyataannya wanita yang bekerja selalu menghadapi dan mengalami konflik untuk menyelaraskan rumah tangga, pekerjaan atau karier dan pendidikan anak. Akibatnya, ia mengalami rintangan-rintangan yang dapat menghambat kemajuan karir dan pribadinya. Itulah fenomena dimana wanita sebagai ibu rumah tangga yang harus melaksanakan tugas didalam lingkungan keluarga tetapi harus bekerja di luar rumah secara rutin pada pagi hari, dan pulang sore hari atau malam hari atau keluar kota dikarenakan tugas kantor. Hal ini terjadi pada para wanita atau ibu rumah tangga di Jl. Anggrek RT 002 RW 018 Pondok Benda Pamulang, mereka bukan hanya sekedar ibu rumah tangga, tetapi mereka juga ada yang memiliki profesi sebagai guru, karyawan swasta dan wiraswasta. Karir tersebut yang membuat mereka sibuk dengan pekerjaan sehingga sedikit sekali waktu yang dapat diluangkan untuk berkumpul bersama keluarga, dan waktu untuk memperhatikan pendidikan anak juga sedikit.

Oleh karena itu, kita tidak dapat pungkiri bahwa wanita menempati posisi sentral dalam keluarga dan pendidikan anak. Akan tetapi problematika muncul lebih kompleks, ketika wanita mulai mengembangkan karier dan bekerja di luar rumah.Berdasarkan masalah di atas maka peneliti mengambil penelitian yang berjudul "Peranan Wanita Karir Profesional Dalam 
Keluarga, Pola Asuh dan Pendidikan Anak (Studi Kasus Pada Wanita Karier Pada Jl. Anggrek RT 002 RW 018 Pondok Benda Pamulang)".

\section{TINJAUAN PUSTAKA}

\section{Pengertian Wanita Karier}

Wanita karier adalah wanita
yang berpendidikan tinggi dan
mempunyai status yang tinggi dalam
pekerjaannya, yang berhasil dalam
berkarya yang dikenal sebagai
wanita bekerja atau wanita berkarya.
Apa yang disebut wanita karier ialah menemukan perwujudan dirinya di dalam dunia kerja. Istilah karier berarti perjalanan yang memperlihatkan kemajuan terus menerus dalam hubungan dengan bekerja, istilah ini berarti suatu pekerjaan atau profesi yang memerlukan pendidikan khusus dan merupakan suatu panggilan, yang dimaksudkan sebagai pekerjaan seumur hidup. Dengan demikian, wanita karier ialah wanita yang melaksanakan, menekuni dan mencintai suatu pekerjaan secara penuh dalam waktu yang lama, untuk mencapai kemajuan dalam hidup, pekerjaan maupun jabatan.

\section{Peran Wanita Karier Dalam Keluarga}

Pengertian peran wanita adalah serangkaian perilaku yang diharapkan sesuai dengan posisi social yang diberikan kepada wanita.
Peran menerangkan pada apa yang harus dilakukan wanita dalam suatu situasi tertentu agar dapat memenuhi harapan mereka sendiri dan harapan orang lain. Peran dan tugas wanita dalam keluarga secara garis besar dibagi menjadi tiga, yaitu:

1. Peran wanita sebagai ibu

2. Peran wanita sebagai istri pendamping suami

3. Peran wanita dalam masyarakat

\section{Pengertian Pola Asuh}

Pola asuh adalah bagaimana cara orang tua mendidik anak, baik secara langsung maupun tidak langsung. Menurut Mussen dalam Tridhonanto Al dan Baranda Agency (2009:11) pola asuh orang tua digolongkan menjadi tiga bentuk pengasuhan, yaitu:

1. Pola asuh otoriter. Pola asuh otoriter ditunjukkan dengan adanya penggarisan norma oleh orang tua serta kontrol yang ketat pada anak guna mendapat kepatuhan dan ketaatan yang mutlak.

2. Pola asuh permisif. Pola asuh permisif merupakan bentuk pengasuhan dimana orang tua sepunuhnya memandang anak sebagai pribadi yang memiliki otonomi terhadap dirinya sendiri.

3. Pola asuh demokratis. Pola asuh demokratis merupakan motode yang digunakan orang tua dimana mereka memberikan penjelasan 
dalam membuat peraturan dan perilaku yang diharapkan dengan bertambahnya usia anak. Tidak hanya sampai disitu, anak juga diberi kesempatan untuk menyatakan pendapat mengenai peraturan yang dibuat.

\section{Peran Wanita Karier Dalam Pendidikan Anak}

Pendidikan ialah bimbingan yang diberikan kepada anak dalam masa pertumbuhan dan perkembangannya untuk mencapai tingkat kedewasaan dan bertujuan untuk menambah ilmu pengetahuan, membentuk karakter diri, dan mengarahkan anak untuk menjadi pribadi yang lebih baik. Pendidikan juga bisa diartikan sebagai usaha sadar yang bertujuan untuk menyiapkan peserta didik dalam belajar melalui suatu kegiatan pengajaran, bimbingan, dan latihan demi peranannya dimasa yang akan datang. Pendidikan yang diberikan kepada anak diantaranya:

1. Pendidikan Aqidah. Pengetahuan yang pertama kali dikenalkan pada anak adalah seputar tauhid, yakni upaya sang anak untuk mengetahui dan meyakini akan adanya Tuhan.

2. Pendidikan Ibadah. Ibadah adalah hal yang paling urgen dalam menjalin komunikasi dengan sang Khalik. Ketika ibu menjalani kehamilan sampai melahirkan, tidaklah berat baginya untuk mengajak si calon bayi untuk ikut serta dalam melakukan ibadah harian. Seperti sholat, puasa, baca Al-Quran, berdoa, berdzikir, dan lain sebagainya.

3. Pendidikan Akhlak. Akhlak merupakan sebuah karakter yang melekat dalam hati, kebiasaanlah yang akan membentuknya. Anak balita memiliki tingkat kecerdasan yang cukup tinggi untuk menangkap sesuatu di lingkungannya. Kepekaan dan daya tangkap yang dimiliknya mampu menirukan apa yang dilihat olehnya. Perilaku yang baik dari orang tua dalam keseharian bisa menjadi faktor utama dalam pengembangan karakter dan kepribadian yang baik si balita. Pembiasaan akhlak yang baik tidak perlu menunggu anak dewasa dari kecil harus sudah dibiasakan.

4. Tarbiyah Aqliyyah (Akal). Pengasahan otak semenjak kecil akan lebih bagus dan lebih terpatri dalam otak anak. Bagai sebuah pisau, semakin lama waktu mengasahnya, maka akan semakin tajam. Dalam hal ini seorang ibu bisa mengajarkan berbagai hal untuk mengasah otak anak. Misalnya dengan mewarnai, menggambar, menghafal, menulis, atau membaca.

Dengan demikian, dalam hal mendidik anak, ibu harus memperhatikan langkah-langkah di bawah ini agar berhasil dengan baik: 
1. Memberi peringatan atau ilmu pengetahuan tentang apa saja yang ditanam (didikan) ibu pada anak, misalnya sholat, apa sholat itu, caranya bagaimana, untuk apa dan lain-lain.

2. Memberi teladan sebab anak suka meniru apa yang dilihatnya.

3. Anjuran, perintah dan latihanlatihan. Dengan anjuran dan perintah, anak bisa mendengar dan mengerti hal-hal yang harus dilaksanakan, sedangkan latihanlatihan menjadikan mereka mengalami sendiri dan dapat melaksanakan dengan baik halhal yang dianjurkan dan diperintahkannya.

4. Hadiah dan sejenisnya. Hadiah ini tidak selalu berupa barang, bisa berupa pujian, dengan acungan jempol, senyuman dan lain-lain. Hal ini dapat memenuhi dorongan perkenan, menggem- birakan anak, menambah percaya diri dan membantu anak dalam mengenal nilai-nilai.

5. Kompetisi dan Kooperasi. Kompetisi dalam proses pendidikan ini dalam arti yang sehat, misalnya lomba (biasanya di luar rumah).Mengenai kooperasi yang dimaksud adalah kerja sama dalam melaksanakan kewajiban dalam keluarga, misalnya sholat jama'ah, belajar membaca Al Qur'an bersama lain-lain. Manfaatnya dapat menumbuhkan rasa simpati dan penghargaan pada pihak lain dan menambah rasa percaya diri.

6. Koreksi dan Pengawasan. Hal ini merupakan tindakan preventif (pencegahan) sebelum ada pelanggan. Karena anak/manusia punya kecenderungan berbuat baik dan sekaligus berbuat jelek/melanggar. Ketika jiwa anak mulai menjurus pada keburukan, maka dengan koreksi dan pengawasan ini ibu segera dapat meluruskannya.

7. Larangan. Dengan larangan ini supaya anak mengetahui dengan jelas hal-hal yang harus ditinggalkan dan dijauhi. Hal ini agar disampaikan pada anak dengan bijaksana, sehingga jiwa anak tidak tertekan.

8. Hukuman dan sejenisanya. Hukuman ini merupakan tindakan terakhir yang boleh dilakukan ibu setelah ditempuh langkah-langkah 1-7 masih belum berhasil juga. Tujuan adalah untuk mendisiplinkan dan menginsyafkan. Tidak selamanya menyakitkan badan tetapi bisa berbentuk apa saja yang menimbulkan rasa tidak enak pada anak.

9. Do'a orang tua (ibu), karena do'a ibu punya peran yang besar terhadap keberhasilan anak.

\section{Problematika dan Dampak Wanita} Karier 
Diantara problematika wanita yang bekerja di luar rumah atau berkarier adalah:

1. Wanita karier merasa bersalah dan ragu, terutama bila dikaitkan dengan kepentingan anaknya.

2. Disatu sisi perempuan diharuskan mempertahankan peran tradisionalnya, sedang disisi lain perempuan diharapkan sukses dalam peran publiknya.

3. Perempuan yang berkarier cukup terbebani dengan kenakalan anak-anak yang selalu dianggap sebagai ekses seorang ibu yang keluar rumah.

4. Jika wanita bekerja dan mempunyai penghasilan lebih besar dari suaminya maka akan menimbulkan rasa tidak enak bagi dirinya, demikian halnya dengan suami juga merasa tidak enak karena yang seharusnya memberikan nafkah adalah suami.

5. Keterbatasan waktu ibu yang bekerja akan mengurangi waktunya mengasuh anak di rumah, dimana usia dini sangat memerlukan kehadiran dan kehangatan kasih sayang ibunya".

6. Bagi wanita yang bekerja diluar rumah, waktu yang digunakan sangat banyak, sebagai akibatnya frekuensi bertemunya dengan keluarga sangat terbatas baik dengan suami dan anakanaknya.
7. Wanita yang berkarier tiak dapat berfungsi penuh sebagai ibu rumah tangga, padahal fungsi ini mutlak harus ada setiap keluarga. Sebab kalau istri bekerja lalu siapa yang harus menghibur suaminya sehabis pulang kerja.

\section{Demikian diantaranya hal-hal} pokok yang menjadi permasalahan/problem utama yang dihadapi oleh istri yang bekerja diluar rumah. Adapun konsekuensi negatif yang terjadi akibat dari ibu rumah tangga yang bekerja yaitu:

1. Pada anak-anak, yaitu meningkatkan risiko terjerumusnya anak-anak kepada hal yang negatif, seperti tindak kriminal yang dilakukan sebagai akibat dari kurangnya kasih sayang yang diberikan orangtua, khususnya Ibu terhadap anakanaknya.

2. Pada suami, yaitu memiliki perasaan tersaingi dan tidak terpenuhi hak-haknya sebagai suami.

3. Pada rumah tangga, memiliki risiko kegagalan rumah tangga terkait ketidakmampuan istri mengurus rumah tangga atau sibuk berkarir.

4. Pada masyarakat, yaitu bertambahnya pengangguran untuk pria dikarenakan wanita mengambil alih pekerjaannya. Hal ini juga terkait dengan permintaan perusahaan dimana 
lebih memilih wanita ketimbang pria karena upah yang murah dan anggapan wanita tidak terlalu banyak menuntut dan mudah diatur.

\section{Dampak Wanita Karier}

Adapun dampak positif wanita karier, yaitu:

1. Terhadap kondisi ekonomi keluarga.

Dengan berkarir, seorang wanita tentu saja mendapatkan imbalan yang kemudian dapat dimanfaatkan untuk menambah dan mencukupi kebutuhan seharihari.Pratiwi Sudamona mengatakan bahwa pria dan wanita adalah "Mitra Sejajar" dalam menunjang perekonomian keluarga. Dalam konteks pembicaraan keluarga yang modern, wanita tidak lagi dianggap sebagai mahluk yang semata-mata tergantung pada penghasilan suaminya, melainkan ikut membantu berperan dalam meningkatkan penghasilan keluarga untuk satu pemenuhan kebutuhan keluarga yang semakin bervariasi.

\section{Sebagai Pengisi Waktu}

Pada zaman sekarang ini hampir semua peralatan rumah tangga memakai teknologi yang mutakhir, khususnya di kota-kota besar. Sehingga tugas wanita dalam rumah tangga menjadi lebih mudah dan ringan. Belum lagi mereka yang menggunakan jasa pramuwisma (pembantu rumah tangga), tentu saja tugas mereka di rumah akan menjadi sangat berkurang. Hal ini bisa menyebabkan wanita memiliki waktu luang yang sangat banyak dan seringkali membosankan. Maka untuk mengisi kekosongan tersebut diupayakanlah suatu kegiatan yang dapat dijadikan sebagai alat untuk mengembangkan potensi yang ada dalam diri mereka.

3. Peningkatan sumber daya manusia

Kemajuan teknologi di segala bidang kehidupan menuntut sumber daya manusia yang potensial untuk menjalankan teknologi tersebut. Bukan hanya pria bahka wanitapun dituntut untuk bisa dapat mengimbangi perkembangan teknologi yang makin kian pesat.Jenjang pendidikan yang tiada batas bagi wanita telah menjadikan mereka sebagai sumber daya potensial yang diharapkan dapat mampu berpartisipasi dan berperan aktif dalam pembangunan, serta dapat berguna bagi masyarakat, agama, nusa dan bangsanya.

4. Percaya diri dan lebih merawat penampilan

Biasanya seorang wanita yang tidak aktif di luar rumah akan malas untuk berhias diri, karena ia merasa tidak diperhatikan dan kurang bermanfaat. Dengan berkarir, maka wanita merasa dibutuhkan dalam masyarakat sehingga timbullah kepercayaan diri. Wanita karir akan berusaha untuk memercantik diri dan penampilannya agar selalu enak dipandang. Tentu hal ini akan menjadikan kebanggaan 
tersendiri bagi suaminya, yang melihat istrinya tampil prima di depan para relasinya.

Adapun dampak negatif wanita karier, yaitu:

1. Terhadap Anak

Seorang wanita karir biasanya pulang ke rumah dalam keadaan lelah setelah seharian bekerja di luar rumah, hal ini secara psikologis akan berpengaruh terhadap tingkat kesabaran yang dimilikinya, baik dalam menghadapi pekerjaan rumah tangga sehari-hari, maupun dalam menghadapi anak-anaknya. Jika hal itu terjadi maka sang Ibu akan mudah marah dan berkurang rasa pedulinya terhadap anak.

2. Terhadap Suami.

Di kalangan para suami wanita karir, tidaklah mustahil menjadi suatu kebanggaan bila mereka memiliki istri yang pandai, aktif, kreatif, dan maju serta dibutuhkan masyarakat, Namun dilain sisi mereka mempunyai problem yang rumit dengan istrinya. Mereka juga akan merasa tersaingi dan tidak terpenuhi hak-haknya sebagai suami. Sebagai contoh, apabila suatu saat seorang suami memiliki masalah di kantor, tentunya ia mengharapkan seseorang yang dapat berbagi masalah dengannya, atau setidaknya ia berharap istrinya akan menyambutnya dengan wajah berseri sehingga berkuranglah beban yang ada. Hal ini tak akan terwujud apabila sang istri pun mengalami hal yang sama. Jangankan untuk mengatasi masalah suaminya, sedangkan masalahnya sendiripun belum tentu dapat diselesaikannya.

3. Terhadap Rumah Tangga.

Kemungkinan negatif lainnya yang perlu mendapat perhatian dari wanita karir yaitu rumah tangga. Kegagalan rumah tangga seringkali dikaitkan dengan kelalaian seorang istri dalam rumah tangga. Hal ini bisa terjadi apabila istri tidak memiliki keterampilan dalam mengurus rumah tangga, atau juga terlalu sibuk dalam berkarir, sehingga segala urusan rumah tangga terbengkalai. Untuk mencapai keberhasilan karirnya, seringkali wanita menomorduakan tugas sebagai ibu dan istri. Dengan demikian pertengkaran bahkan perpecahan dalam rumah tangga tidak bisa dihindarkan lagi.

4. Terhadap Masyarakat.

Hal negatif yang ditimbulkan oleh adanya wanita karir tidak hanya berdampak terhadap keluarga dan rumah tangga, tetapi juga terhadap masyarakat sekitarnya, seperti halhal berikut:

Dengan bertambahnya jumlah wanita yang mementingkan karirnya di berbagai sektor lapangan pekerjaan, secara langsung maupun tidak langsung telah mengakibatkan meningkatnya jumlah pengangguran di kalangan pria, karena lapangan pekerjaan yang ada telah diisi oleh wanita. Sebagai contoh, yang sering kita lihat di pabrik-pabrik. Perusahaan lebih memilih pekerja 
dari kalangan wanita ketimbang pria, karena selain upah yang relatif minim dan murah dari pria, juga karena wanita tidak terlalu banyak menuntut dan mudah diatur.

Kepercayaan diri yang berlebihan dari seorang wanita karir seringkali menyebabkan mereka terlalu memilih-milih dalam urusan perjodohan. Dan sementara itu dilain sisi pria-pria yang menjadi dambaan para wanita karir ini -kemungkinan karena terlalu tinggi kriterianyatelah lebih dulu berkeluarga dan membina rumah tangga dengan wanita lain. Hal inilah mungkin yang menyebabkan timbulnya anggapan dalam masyarakat bahwa semakin tinggi jenjang pendidikan yang dapat diraih oleh wanita maka semakin sulit pula baginya untuk mendapatkan pendamping hidup.

\section{METODOLOGI PENELITIAN Tempat Penelitian}

Penelitian tentang Peranan Wanita Karier dalam Keluarga, Pola Asuh dan Pendidikan Anak (Studi Kasus Pada Wanita Karier) akan dilakukan di Jl. Anggrek RT 002/018 Pondok Benda Pamulang.

\section{Waktu Penelitian}

Waktu penelitian adalah rentang waktu yang digunakan untuk melaksanakan penelitian sejak dari awal hingga selesai. Adapun waktu penelitian ini akan dilaksanakan selama enam bulan, yaitu dari bulan
Desember 2015 sampai dengan Maret 2016.

\section{Alasan penelitian menggunakan metode kualitatif}

Dalam penelitian ini peneliti menggunakan metode kualitatif atau naturalistik karena dilakukan pada kondisi yang alamiah dan kualitatif menawarkan kemudahan dan kebebasan untuk mendapatkan informasi dari key informan sebagai data yang akurat.Dan Moleong (2010:35) menyatakan bahwa penelitian kualitatif merupakan penelitian yang bermaksud untuk memahami fenomena tentang apa yang dialami oleh subyek penelitian, misalnya perilaku, persepsi, motivasi, tindakan yang dilakukan secara holistik dan dengan cara deskriptif dalam bentuk kata-kata dan Bahasa dalam suatu konteks khusus yang alamiah dan dengan memanfaatkan berbagai metode ilmiah.Sebagaimana yang menjadi corak penelitian deskriptif kualitatif, bahwa penelitian kualitatif tidak hanya menetapkan penelitiannya hanya berdasarkan variabel penelitian, tetapi keseluruhan situasi sosial yang diteliti yang meliputi aspek tempat (place), pelaku (actor) dan aktivitas (activity) yang berinteraksi secara sinergis, Sugiyono (2012:287).

Adapun pendekatan yang dilakukan dalam penelitian ini adalah pendekatan studi kasus. Menurut 
Creswell dalam Sugiyono (2012:14), Studi kasus merupakan salah satu jenis penelitian kualitatif, dimana peneliti melakukan eksplorasi secara mendalam terhadap program, kejadian, proses, aktivitas, terhadap satu atau lebih orang. Dan dalam penelitian ini peneliti menggunakan teknik purposive sampling. Menurut Sugiyono (2012:126) teknik purposive sampling yaitu teknik penentuan sampel dengan pertimbangan tertentu. Dan peneliti mengambil sampel atau nara sumber yang dianggap penting dan paling mengetahui tentang apa yang kita harapkan sehingga akan memudahkan peneliti dalam menjelajahi obyek atau situasi sosial yang diteliti.

\section{Desain Penelitian}

Desain penelitian merupakan suatu alat yang menuntun peneliti dalam melakukan penelitian. Dalam desain penelitian ini peneliti memiliki pedoman atau arahan dalam melakukan pengumpulan data, menganalisis dan menginterpretasikan atau menterjemahkan data yang dikumpulkan dan selanjutnya membuat kesimpulan.

\section{Proposisi Studi}

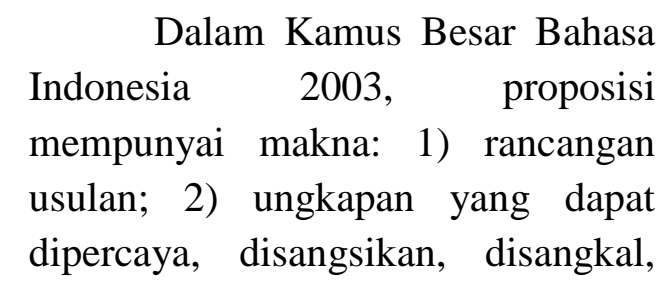

atau dibuktikan benar tidaknya. Adapun proposisi studi dalam penelitian ini adalah:
a. Peran wanita karier terhadap keluarga
b. Pola asuh wanita karier dalam mengasuh anak
c. Peran wanita karier terhadap pendidikan anak
d. Faktor yang mendukung dan menghambat peran wanita karier dalam keluarga, pola asuh (mengasuh anak) dan pendidikan anak.

\section{Unit Analisis}

Menurut Hamidi (2005: 7576) menyatakan bahwa unit analisis adalah satuan yang diteliti yang bisa berupa individu, kelompok, benda atau suatu latar peristiwa sosial seperti misalnya aktivitas individu atau kelompok sebagai subjek penelitian. Dalam penelitian ini unit analisisnya adalah wanita yang bekerja (wanita karier) di Jl. Anggrek dan memiliki anak serta hal-hal yang terkait dalam penelitian.

\section{Keterkaitan Data Untuk Proposisi}

Keterkaitan data untuk proposisi merupakan kegiatan untuk melakukan cara menghubungkan data yang relevan yang dikumpulkan dengan proposisi studi. Hal ini dilakukan untuk memberikan panduan bagi penelitian ini agar lebih terarah dan fokus pada tujuan dari penelitian. Tabel 3.1 
menunjukkan data yang relevan dan

tersebut dengan proposisi studi.

bagaimana data yang relevan

Tabel 3.1. Keterkaitan data dengan proposisi

\begin{tabular}{|c|c|c|c|}
\hline No. & Proposisi & Data yang relevan & Keterangan \\
\hline 1. & $\begin{array}{l}\text { Peran wanita } \\
\text { karier dalam } \\
\text { keluarga }\end{array}$ & $\begin{array}{l}\text { 1. Kegiatan apa saja yang } \\
\text { dilakukan saat berada di } \\
\text { rumah. } \\
\text { 2. Sejauh mana komunikasi } \\
\text { wanita karier dengan suami } \\
\text { dan anak. } \\
\text { 3. Cara mereka (wanita karier) } \\
\text { dalam memberikan } \\
\text { perhatian pada keluarga. }\end{array}$ & $\begin{array}{l}\text { Kondisi para ibu yang bekerja yang sibuk akan } \\
\text { tetapi masih dapat mengerjakan tugas rumah } \\
\text { tangga, meskipun terkadang mereka jarang } \\
\text { hadir saat ada acara keluarga. Dan sesibuk } \\
\text { apapun wanita bekerja komunikasi pada suami } \\
\text { dan anak tetap terjalin. Dan pada kenyataanya } \\
\text { wanita yang bekerja memiliki dampak positif } \\
\text { dalam kebutuhan keluarga. }\end{array}$ \\
\hline 2. & $\begin{array}{l}\text { Pola asuh } \\
\text { wanita karier } \\
\text { dalam } \\
\text { mengasuh anak } \\
\text { dan pendidikan } \\
\text { anak. } \\
\text { Peran wanita } \\
\text { karier dalam } \\
\text { pendidikan } \\
\text { anak }\end{array}$ & $\begin{array}{l}\text { 1. Pengasuhan anak diberikan } \\
\text { kepada siapa. } \\
\text { 2. Pembagian waktu antara } \\
\text { kerja dan pendidikan anak. } \\
\text { 3. Pola asuh apa yang } \\
\text { digunakan dalam mendidik } \\
\text { anak. }\end{array}$ & $\begin{array}{l}\text { Kenyataannya wanita memiliki peran penting } \\
\text { dalam mengasuh anak, walaupun kebanyakan } \\
\text { wanita kerier memberikan kepercayaan anggota } \\
\text { keluarga mereka untuk mengasuh anaknya. Dan } \\
\text { seorang wanita yang bekerja di luar rumah } \\
\text { ternyata dapat membagi waktu dalam } \\
\text { memberikan pengajaran dan pendidikan pada } \\
\text { anak dengan menggunakan pola asuh } \\
\text { demokratis. Dan wanita karier sudah } \\
\text { memikirkan pendidikan anaknya sejak dini, } \\
\text { mulai dari memilih sekolah yang unggulan } \\
\text { untuk anak. }\end{array}$ \\
\hline 3. & $\begin{array}{l}\text { Faktor yang } \\
\text { mendukung dan } \\
\text { menghambat } \\
\text { peran wanita } \\
\text { karier dalam } \\
\text { keluarga, pola } \\
\text { asuh (mengasuh } \\
\text { anak) dan } \\
\text { pendidikan } \\
\text { anak. }\end{array}$ & $\begin{array}{l}\text { 1. Hal apa saja yang } \\
\text { mengganggu aktivitas } \\
\text { rumah tangga. } \\
\text { 2. Tanggapan suami dan anak } \\
\text { tentang pekerjaan wanita } \\
\text { karier. }\end{array}$ & $\begin{array}{l}\text { Faktanya pekerjaan kantor yang banyak menyita } \\
\text { waktu sehingga pekerjaan rumah tangga } \\
\text { terbengkalai. Akan tetapi dorongan suami } \\
\text { dalam berusaha untuk bersama mengatur rumah } \\
\text { tangga atau keluarga motivasi bagi wanita } \\
\text { karier dan memberikan kesempatan wanita } \\
\text { bekerja agar maju dan berkembang, akan tetapi } \\
\text { tidak melepaskan diri dari tanggungjawab } \\
\text { dalam keluarga, sebagai istri dan ibu dari } \\
\text { anaknya. }\end{array}$ \\
\hline
\end{tabular}

\section{Kriteria Interpretasi Temuan}

1. Data diperoleh dari sumbersumber yang relevan dan bukan merupakan asumsi subjektif.

2. Data dapat diinterpretasikan dengan objektif, sesuai dengan fakta dan menghilangkan unsur bias dan kesalahan.

3. Data diperoleh dari informan kunci dengan mengalami perubahan, dari pernyataan bahwa wanita dapat bekerja di luar rumah dan dapat melakukan perannya dalam keluarga sebagai ibu maupun istri.
Dengan demikian wanita tidak akan lupa dengan kewajibannya sebagai ibu rumah tangga.

4. Data diperoleh dari informan kunci dengan pernyataan bahwa sesibuk apapun pekerjan yang dijalani, seorang ibu yang bekerja harus mengasuh anaknya dengan baik dengan menerapkan pola asuh yang baik bagi anak, karena dengan asuhan yang baik anak akan tumbuh dengan baik pula.

5. Dan data diperoleh dari informan kunci dengan pernyataan bahwa pendidikan 
anak itu sangat penting karena hal tersebut menyangkut masa depan anak mereka kelak. Dengan memberikan pendidikan moral dan nilai-nilai agama.

6. Dan adapun faktor yang mendukung dan menghambat yang diperoleh dari data informan kunci yaitu adanya dorongan atau izin dari suami dan anak untuk bekerja, dan penghambatnya yaitu terkadang sulit dalam membagi waktu.

\section{Kriteria Uji Kualitas Desain Penelitian}

Dalam pengujian keabsahan data, metode penelitian kualitatif menggunakan istilah yang berbeda dengan penelitian kuantitatif. Menurut Sugiyono (2012:364) jika uji keabsahan data dalam penelitian kualitatif meliputi uji, credibility (validitas internal), transferability (validitas eksternal), dependability (reliabilitas), dan confirmability (obyektivitas).

\section{Validitas Internal (credibility)}

a. Meningkatkan ketekunan, yaitu dengan melakukan pengamatan secara lebih cermat dan berkesinambungan dengan mengecek data penelitian tentang peran wanita karier dalam keluarga, pola asuh dan pendidikan anak yang telah dikerjakan, ada yang salah atau tidak. b. Menggunakan

Bahan Referensi, yang dimaksud dengan bahan referensi disini adalah adanya pendukung untuk membuktikan data yang telah ditemukan oleh peneliti. Dengan demikian, dalam penelitian ini peneliti menggunakan alat bantu camera dan alat perekam untuk mendapatkan data yang akurat dari wawancara.

c. Peninjauan kembali draft laporan studi kasus yang bersangkutan oleh key informan, yaitu dengan melihat keterkaitan yang eksplisit antara pertanyaanpertanyaan yang diajukan, data yang terkumpul dan simpulan yang diambil.

d. Diskusi teman sejawat, yakni diskusi yang dilakukan dengan rekan yang mampu memberikan masukan ataupun sanggahan sehingga memberikan kemantapan terhadap hasil penelitian.

\section{Validitas}

Eksternal (transferability)

Dalam Sugiyono (2012:373) validitas eksternal menunjukkan derajat ketepatan atau dapat diterapkannya hasil penelitian ke populasi di mana sampel tersebut diambil dan bagi penelitian kualitatif nilai transfer bergantung pada pemakai, hingga manakala hasil penelitian tersebut dapat digunakan dalam konteks dan situasi sosial lain. 
Oleh karena itu, dalam penelitian ini supaya orang lain dapat memahami hasil penelitian sehingga ada kemungkinan untuk menerapkan hasil penelitian tersebut, maka peneliti dalam membuat laporannya dengan uraian yang rinci, jelas, dapat dipercaya dan dengan menggunakan bahasa yang mudah dipahami oleh pembaca.

\section{Reliabilitas (dependability)}

Dalam Danim (2002:205)

dikemukakan bahwa untuk menentukan reliabilitas penelitian, dilakukan empat hal. Pertama, mengecek secara langsung keberhasilan penelitian. Kedua, memperoleh keterangan atau menangkap fenomena penelitian dengan menerapkan berbagai metode. Ketiga, pencapaian keterandalan penelitian melalui replikasi. Keempat, melalui pemeriksaan penelitian mirip dengan pemeriksaan pembukuan.Dalam keempat hal yang dikemukakan oleh Danim, tiga di antaranya yang digunakan dalam penelitian tentang peran wanita karier dalam keluarga, pola asuh dan pendidikan anak, yaitu pertama mengecek secara langsung keberhasilan penelitian. Kedua, memperoleh keterangan, dan ketiga memeriksa penelitian mirip dengan memeriksa pembukuan (artikel, buku-buku dan jurnal).

\section{Obyektivitas (confirmability)}

Dalam Sugiyono (2012:374) dikemukakan bahwa pengujian obyektivitas dalam penelitian berarti menguji hasil penelitian, dikaitkan dengan proses yang dilakukan. Oleh karena itu, dalam penelitian ini peneliti melakukan pengecekan dari data-data yang diperoleh baik dari observasi di lapangan, wawancara dan kuesioner juga dari buku-buku yang terkait dengan peran wanita dalam keluarga, pola asuh dan pendidikan anak. Jika semua sudah sesuai atau sudah valid maka penelitian tersebut sudah memenuhi standar confirmability.

\section{Jenis dan Sumber Data}

Dalam penelitian ini, peneliti menggunakan jenis dan sumber data primer dan sekunder. Dalam penelitian ini sumber data primer yaitu dari wawancara dan observasi langsung kepada para wanita karier dari lokasi penelitian. Dan data sekunder yaitu dari buku-buku, artikel dan jurnal yang berkaitan dengan peran wanita karier dalam keluarga, pola asuh dan pendidikan anak.

\section{Teknik Pengumpulan Data}

\section{Observasi.}

Observasi adalah suatu proses melihat, mengamati, mencermati, dan merekam perilaku secara sistematis untuk suatu tujuan tertentu. Inti dari observasi adalah adanya perilaku yang tampak dan tujuan yang ingin dicapai. Perilaku yang tampak dapat berupa perilaku yang dapat dilihat oleh mata, didengar, dihitung atau dapat diukur. 
Herdiansyah (2012:53). Dalam pelaksanaannya peneliti mengamati kegiatan yang dilakukan oleh subjek dan mengamati subjek dalam menjawab pertanyaan-pertanyaan peneliti selama wawancara berlangsung.

2. Wawancara

Metode wawancara yang digunakan, metode wawancara campuran dengan menggabungkan metode terpimpin (terstruktur) dengan metode bebas (tidak terikat) dengan cara peneliti membuat pedoman wawancara terlebih dahulu yang kemudian digunakan dalam proses wawancara dengan pengembangan secara bebas sebanyak mungkin sesuai kebutuhan data yang ingin diperoleh. Dan untuk menunjang hasil wawancara, peneliti menggunakan kuesioner sebagai bahan pendukung penelitian.

3. Studi Kepustakaan dan Dokumentasi

Merupakan metode dengan jalan mencari keterangan-keterangan teori-teori dan data yang lain diperlukan dalam pembahasan penelitian ini melalui buku-buku literature dan peraturan perundangundangan. Dan dokumentasi digunakan untuk memperoleh data tentang foto atau gambar kehidupan dari objek penelitian. Dengan demikian, peneliti mencari data dari berbagai sumber melalui buku kajaian ilmiah, makalah dan dari sumber lainnya yag mendukung peneliti dalam menyelesaikan penelitian.

\section{Teknik Analisis Data}

Adapun analisis yang akan digunakan adalah analisa kualitatif model interaktif (interactive model of analysis) yaitu dengan cara interaksi, baik antara komponennya, maupun dengan proses pengumpulan data dalam proses yang berbentuk siklus. Dan seperti yang dikemukakan oleh Miles dan Huberman bahwa aktivitas dalam analisis data kualitatif dilakukan secara interaktif dan berlangsung secara terus menerus sampai tuntas, sehingga datanya sudah jenuh (Sugiyono, 2012:334).

\section{HASIL PENELITIAN}

1. Peran Wanita karier Dalam Keluarga

Peneliti melakukan

wawancara dengan pertanyaan dalam hal peran wanita karier dalam keluarga, dari hasil wawancara dan penyebaran kuesioner sebagai pendukung penelitian terlihat bahwa para wanita karier di Jl. Anggrek RT 002/018 Pondok Benda Pamulang berpandangan atau berasumsi bahwa wanita karier itu bukan hanya wanita yang bekerja di luar rumah untuk mendedikasikan ilmu yang didapat, akan tetapi membantu suami untuk memenuhi kebutuhan dalam rumah tangga dan untuk mengisi waktu luang disebabkan kata mereka dapat mencukupi uang jajan anak-anak dan 
perlengkapan sekolah juga dapat membeli keperluan pribadi sendiri.

Dan peran wanita dalam keluarga amatlah penting meskipun wanita juga bekerja di luar rumah. Para wanita karier di Jl. Anggrek tetap melakukan tugasnya sebagai ibu rumah tangga meskipun mereka juga mempunyai kesibukan di luar rumah dengan bekerja. Mereka melakukan tugasnya sebagai ibu rumah tangga seperti menyiapkan sarapan, menyiapkan keperluan suami dan anak, berkumpul bersama keluarga saat libur kerja, sebisa mungkin menyempatkan waktu untuk mengantarkan anak kesekolah, menyempatkan waktu untuk hadir jika ada acara keluarga dan selalu menjalin komunikasi dengan suami dan anak. Walaupun terkadang mereka melalukan tugas rumah tangga di bantu oleh asisten rumah tangga dan jarang bersosialisasi dengan lingkungan sekitar, mereka tetap memperhatikan, melayani, melindungi dan memberikan kenyamanan bagi keluarga mereka.

2. Pola Asuh Wanita Karier Dalam Mengasuh dan Pendidikan Anak Peneliti melakukan wawancara dengan pertanyaan dalam hal mengasuh dan pendidikan anak, dari responden sebagai key informan dan dari hasil kuesioner, mereka menyatakan bahwa dalam mengasuh anak, mereka demokratis dalam mengasuh anak-anak mereka. Mereka memberikan kebebasan kepada anak mereka, akan tetapi tetap terkontrol dan jika ada yang salah maka mereka selalu menasehati anak mereka. Dan dalam mengasuh anak, mereka dibantu oleh keluarga karena mereka merasa aman jika anak-anak mereka dititipkan atau diasuh oleh keluarga mereka sendiri. Meskipun mereka di bantu keluarga dalam mengasuh anak, mereka tetap memantau perkembangan atau tumbuh kembang anak-anak mereka. Dalam mengasuh anak, mereka tidak lupa untuk menanamkan dan menerapkan nilai-nilai agama sebagai pondasi keimanan ketika anak mereka dewasa.

$\begin{array}{rrr}\text { Dan } & \text { mereka } & \text { sudah } \\ \text { memikirkan } & \text { bahkan } & \text { sudah }\end{array}$ menyiapkan biaya pendidikan untuk anak mereka dan sudah memilih sekolah yang baik dan bagus untuk anak mereka sekolah dan sesibuk apapun mereka dalam bekerja mereka tetap memperhatikan anakanak mereka, mereka tetap membantu anak mereka jika ada kesulitan dalam belajar dan jika libur kerja mereka mengantar anak kesekolah.

3. Faktor Pendukung dan Penghambat Wanita Karier dalam keluarga dan Pola Asuh dalam Mendidik Anak Juga Pendidikannya

Peneliti melakukan wawancara dengan pertanyaan dalam hal faktor yang mendukung maupun yang menghambat wanita karier dalam keluarga dan pola asuh maupun pendidikan anak, dari 
responden sebagai key informan dan dari hasil kuesioner, mereka menyatakan bahwa faktor pendukung mereka dalam bekerja karena adanya:

a. Dukungan dan izin dari pasangan dan anak mereka untuk bekerja.

b. Kerjasama dan komunikasi yang baik dengan pasangan dan anak membuat mereka tidak khawatir akan keadaan keluarganya.

Akan tetapi, ada faktor penghambat yaitu:

a. waktu yang dirasakan terlalu sempit yang membuat para ibu sering dalam keadaan terburuburu dan tertekan.

b. Ibu merasa tidak tenang bekerja bila anak atau suami sedang sakit.

c. Apabila orang-orang yang membantu pekerjaan domestik, pengasuh, atau keluarga yang sudah biasa mengasuh dan menemani anak yang sedang sakit atau pergi meninggalkan keluarga tersebut.

d. Tenaga yang terbatas yaitu pada saat badan yang terlalu lelah karena sudah seharian bekerja akan tetapi ingin mengerjakan semua tugas rumah tangga dan memenuhi semua fungsi secara memuaskan.

\section{KESIMPULAN}

1. Bahwa menjalani peran ganda bagi wanita karier tidaklah mudah, tetapi para informan dan hasil dari responden menujukkan bahwa wanita karier dapat melewati peran ganda tersebut dengan baik, meskipun sibuk diluar rumah, wanita karier tetap bisa melaksanakan kewajibannya sebagai ibu rumah tangga yang memberikan perhatian penuh pada suami dan anak. Dan wanita karier selalu berusaha untuk menerapkan pola asuh yang baik dan benar bagi anak dan pendidikan anak agar tumbuh kembang dan pendidikan anaknya baik. Dan alasan yang menyebabkan ibu bekerja bukan hanya untuk membantu kebutuhan keluarga akan tetapi juga untuk memanfaatkan pendidikan yang dimiliki. Dan ibu yang bekerja atau wanita karier tetap dapat mengurus rumah tangganya dan memenuhi kebutuhan anaknya.

2. Dengan pola asuh demokratis, wanita karier mengasuh anakanak mereka dengan penuh kasih sayang dan memberikan kesempatan pada anak untuk mengembangkan wawasannya tapi tetap ada pengawasan dari orang tua.

3. Wanita karier memberikan motivasi tentang pendidikan moral dan agama, seperti mengajarkan untuk mengasihi sesama dan saling berbagi, sholat dan mengaji.

4. Faktor penghambat wanita karier adalah waktu dan tenaga yang 
terbatas, karena waktu dan tenaga yang dijalani harus dibagi untuk mengurus keluarga, pekerjaan, dan untuk mengasuh dan memberikan pendidikan pada anak dan tidak jarang pula wanita karier melakukan hal itu dengan tergesa-gesa dan kurang maksimal. Dan faktor pendukung adalah peluang atau kesempatan berkomunikasi antar keluarga. Dan dengan adanya izin dari suami yang memperbolehkan sang istri bekerja.

\section{SARAN}

1. Bagi wanita karier diharapkan dapat mendisiplinkan atau mengatur waktu untuk dapat memaksimalkan perannya sebagai ibu rumah tangga, istri sekaligus wanita yang bekerja sehingga terciptanya keluarga yang sejahtera.

2. Para orang tua, terutama ibu harus tetap menanyakan perkembangan anak di sekolah. Hal ini bukan berarti bahwa pengawasan yang diberikan berlebihan. Semakin seringnya ibu meluangkan waktu untuk anak, hubungan keduanya semakin erat, sehingga masalah yang dihadapi anak dapat diketahui oleh ibu.

3. Bagi wanita karier harus memenuhi tanggung jawabnya dalam mendidik anak, baik dilembaga formal maupun dilingkungan keluarga sendiri. Maka dari itu anak perlu mengikuti kegiatan positif yang dapat menambah pengetahuan. Seperti les, kursus atau kegiatan organisasi. Organisasi bersifat keagamaan baik untuk diikuti, sebab disamping bakat anak berkembang, juga dapat menguatkan atau mengokohkan agama sebagai dasar hidupnya.

\section{DAFTAR PUSTAKA}

Anwar. 2007. Manajemen

Pemberdayaan Perempuan (Perubahan Sosial Melalui Pembelajaran Vocational Skill Pada Keluarga Nelayan). Bandung: Alfabeta. Basiron, Bushrah. 2006. Wanita Cemerlang. Johor Bahru: Universitas Teknologi Malaysia.

Baswedan, Aliyah Rasyid. 2015. Wanita, Karier dan Pendidikan Anak. Cet.1. Yogyakarta: Ilmu Giri.

Danim, Sudarwan. 2002. Menjadi Peneliti Kualitatif. Bandung: Pustaka Setia.

Daradjat, Zakiyah. 1995. Pendidikan Islam, Keluarga dan Sekolah.

Cet.2. Jakarta: CV Ruhama.

Depdikbud. 2008. Kamus Besar Bahasa Indonesia. Cet.I. Edisi 4. Jakarta: Gramedia Pustaka Utama.

Maghribi, Al-Maghribi bin as-Said. 2007. Begini Seharusnya Mendidik Anak, Panduan 
Mendidik Anak Sejak Masa

Kandungan hingga Dewasa.

Terj. Dari Kaifa Turabbi

Waladan Shalihan oleh

Zainal Abidin, Jakarta:

Darul Haq, Cet. V.

Mahya, Wahyu Nur. 2014. Peran

Ganda Wanita. Sosiologi dan

Antropologi. UNNES.

Mangkunegara, Anwar Prabu. 2011.

Manajemen Sumber Daya

Manusia. Cet.10. Jakarta: PT.

Remaja Rosdakarya.

Moleong, Lexy J. 2007. Metodologi

Penelitian Kualitatif Edisi

Revisi. Bandung: Remaja

Rosdakarya.

Mu'riah, Siti. 2011. Nilai-nilai

Pendidikan Islam dan Wanita

Karier. Semarang: Rasail

Media Group.

Murniati, A. Nunuk P. 2004. Getar

Gender: Buku Kedua.

Magelang: Perpustakaan

Nasional RI: Katalog Dalam

Terbitan (KDT).

Ritzer, dan Goodman. 2010. Teori

Sosiologi Modern. Edisi Ke-

6. Jakarta: Kencana.

Sugiyono. 2012. Metode Penelitian

Kuantitatif, Kualitatif dan

Kombinasi (Mixed Method).

cet.2. Bandung: Alfabeta.

Sukmadi. 2012. Dasar-Dasar

Manajemen. cet.1. Bandung:

Humaniora.

Sunyoto, Danang. 2013. Manajemen

Sumber Daya Manusia.

Cet.2. Yogyakarta: CAPS.
Tridhonanto, Al. 2009. Melejitkan Kecerdasan Emosi (EQ) Buah Hati. Jakarta: PT. Gramedia.

Wuryani, Sri Esti. 2006. Psikologi Pendidikan. Jakarta: Grasindo.

Fadillawati, Evi. 2011. Kesetaraan Gender: Peran Perempuan Dalam Meningkatkan Kesejahteraan Ekonomi Keluarga.

http://id.shvoong.com/socialsciences/sociology/2206415pengertian-wanita-karier/.

Harun Fatmawati. 2010. Faktorfaktor yang mempengaruhi strategi perempuan bekerja dan kesejahteraan keluarga. www.kompasiana.com.

Iklima. 2014. Peran Wanita Karier Dalam Menjalankan Fungsi Keluarga (Studi Kasus PNS Wanita Yang Telah Berkeluarga Di Balai Kota Bagian Humas Dan Protokol Samarinda). E-Journal Sosiatri Integratif, 2 (3): 7789.

Khan, Mahmood Ahmad dan Asma Hassan. 2012. Emotional Intelligence of Children of Working And Non-Working Mothers. Researcher. 4(4):24-31. ISSN: 1553-9865. http://www.sciencepub.net/re searcher.

Manhas, Sarika dan Priya Devi. 2014. Parenting adolescents and preschoolers: a study of 
working mothers of Jammu city. International Journal of Multidisciplinary Research and Development, 1(7): 157161. e-ISSN: 2349-4182. pISSN: 2349-5979.

www.allsubjectjournal.com.

Muhammad, Ummu. 2013. Peran

Wanita Dalam Islam, Peran

Perempuan dalam

Pendidikan.

www.kompasiana.com

Shalom-T uchin, Bosmat. 2013.

Combining Multiple Roles among High Position Women in Israel, as Seen by the Woman, Her Husband and a Child. Journal of International Women's Studies. 14(1): 69-93. http://vc.bridgew.edu/jiws/vol 14/issl/5

Siregar, Mastauli. 2007. Keterlibatan Ibu Bekerja Dalam Perkembangan Pendidikan Anak. Jurnal Harmoni Sosial USU. Vol.2. No.1.

Talita. 2010. Wanita Bekerja. www.kompasiana.com.

Yunita, Awing. 2013. Peran Wanita

Karier Dalam Menjalankan Fungsi Keluarga (Studi

Kasus Pada Wanita Yang Menjabat Eselon di Pemerintah Daerah

Kabupaten Bulungan). EJournal Ilmu Sosiatri, 1 (2): 65-75. 